\title{
PEMANTAUAN KUALITAS AIR SUNGAI CISADANE SECARA ONLINE DAN ANALISA STATUS MUTU AIR MENGGUNAKAN METODE STORET
}

\author{
Devi Ramadhawati' ${ }^{1)}$, Heru Dwi Wahyono ${ }^{2)}$, Arif Dwi Santoso ${ }^{2)}$ \\ 1) Jurusan Manajemen Sumberdaya Perairan, Universitas Brawijaya, Malang, Jawa Timur \\ 2) Pusat Teknologi Lingkungan, Badan Pengkajian dan Penerapan Teknologi, Jakarta \\ E-mail : deviramadha@gmail.com
}

\begin{abstract}
Abstrak
Perubahan kualitas air pada perairan umum seperti Sungai Cisadane mengalami dinamika yang cepat akibat besarnya beban pencemar dari aktivitas masyarakat di sepanjang sungai. Perubahan kualitas air yang cepat ini menuntut diterapkannya inovasi pemantauan kualitas air secara online untuk mengetahui kualitas air sungai dan memperkirakan indikasi sumber pencemaran secara lebih cepat dan realtime, sehingga dapat mencegah pencemaran yang semakin meningkat. Penelitian ini berfokus pada laporan pemantauan kualitas air Sungai Cisadane secara online menggunakan sistem telemetri Onlimo. Sensor yang digunakan terdiri sensor suhu, daya hantar listrik, TDS, kekeruhan, DO, pH, dan nitrat yang ditempatkan di 3 stasiun Sungai Cisadane. Data hasil pemantauan dikirim dan diolah secara online kemudian dianalsis dengan menggunakan metode STORET. Hasil analisis menyatakan bahwa secara umum kondisi kualitas air Sungai Cisadane dalam katagori tercemar sedang, sehingga tidak memenuhi baku mutu peruntukan Kelas II, tertutama untuk parameter TDS, DO, pH dan nitrat.
\end{abstract}

Kata kunci: Metode STORET, Onlimo, Status Mutu Air, Sungai Cisadane

\begin{abstract}
Changes in water quality in public waters such as the Cisadane River have experienced rapid dynamics due to the large pollutant load from community activities along the river. This rapid change in water quality requires the implementation of online water quality monitoring innovations to determine the quality of river water and estimate the indication of pollution sources more quickly and in real time, so as to prevent increasing pollution. This study focuses on monitoring reports of the Cisadane River water quality online using the Onlimo telemetry system. The sensors used consisted of temperature sensors, electrical conductivity, TDS, turbidity, DO, pH, and nitrates placed at 3 Cisadane River stations. The monitoring result was sent and processed online then the authors analyzed using the STORET method. The results of the analysis show that in general the condition of the Cisadane River water quality is in the medium polluted category, so that it does not meet the Class II designation quality standards, especially for the parameters of TDS, DO, pH and nitrate.
\end{abstract}

Keywords: Cisadane River, Onlimo, STORET Methode, Water Quality Status

\section{PENDAHULUAN}

Sungai Cisadane merupakan sungai yang melintasi 44 kecamatan di 5 kabupaten kota yaitu Kabupaten Bogor, Kota Bogor, Kabupaten Tangerang, Kota Tangerang dan Tangerang Selatan. Sungai ini memiliki panjang $126 \mathrm{~km}$ dan luas seluruh area DAS sebesar 151.808 ha. Hulu sungai Cisadane berada di lereng Gunung Pangrango dan aliranya bermuara di laut Jawa (Rosarina dan Laksanawati, 2018). Sungai Cisadane menjadi sumberdaya air yang penting karena berfungsi sebagai sumber air baku PDAM, air baku industri, pertanian dan rumah tangga bagi masyarakat sekitarnya. 
Tingginya aktivitas masyarakat dan industri di sepanjang aliran sungai Cisadane dapat menjadi sumber bahan pencemar yang mengakibatkan terjadinya penurunan kualitas air. Kualitas air sungai Cisadane berrfluktuasi dinamis, namun secara garis besar telah tercemar (Namara et al., 2016). Menurut Siahaan et al. (2011), kualitas air sungai Cisadane dari hulu ke hilir semakin menurun. Bagian hulu sungai ini telah tercemar ringan sementara di bagian hilirnya tercemar berat. Oleh karena itu, kegiatan pemantauan kualitas air sungai perlu dilakukan untuk mencegah pencemaran yang semakin meningkat di sungai Cisadane. Menurut Kurniawan et al. (2014), pemantauan kualitas air sungai penting dilakukan. Sungai sebagai ekosistem terbuka menerima beban pencemaran melalui saluran-saluran air dari berbagai sumber pencemar.

Selama ini, upaya pemantauan kualitas air sungai Cisadane dilakukan secara parsial dan manual dimana pengukuran kualitas air dilakukan sesaat secara in situ dan ex situ (lapang dan laboratorium). Menurut Pamungkas (2017), pemantauan kualitas air secara manual, masih banyak dilakukan oleh instansi pengelolaan lingkungan. Menurut Wahyono (2018), pemantauan kualitas air secara manual memiliki beberapa kekurangan diantaranya membutuhkan waktu yang lama, biaya yang besar serta jarak yang jauh antara lokasi pengambilan sampel dengan laboratorium analisisnya. Oleh karena itu, pemantauan kualitas air secara manual tidak disarankan untuk mengukur kondisi dan kecenderungan kualitas air dalam waktu cepat.

Sehubungan dengan tingginya dinamika perubahan kualitas air dan besarnya beban pencemar yang masuk ke sungai Cisadane, maka upaya pemantauan kualitas air sungai dapat dilakukan secara langsung (online). Pemantauan kualitas air secara online merupakan penerapan teknologi telemetri yang memungkinkan dilakukannya kegiatan monitoring kualitas air secara jarak jauh, sehingga lebih praktis dan efisien. Teknologi Pemantauan kualitas air secara online ini dikembangkan untuk mendukung kegiatan pemantauan kualitas air secara manual yang dirasa kurang efektif, karena besarnya sungai dan banyaknya titik pantau (Wahyono, 2018). Pemantauan kualitas air secara online dapat memberikan data kualitas air secara lebih cepat, realtime dan berkala yang nantinya dapat memberikan informasi terkait status mutu air dan tingkat pencemaran.

Hasil pemantauan kualitas air tersebut, dapat ditrasformasikan menjadi nilai tunggal yang mewakili kondisi dan status mutu perairan (Hendrawan, 2005). Salah satu metode yang sering digunakan untuk menentukan status mutu air sungai adalah metode STORET karena 
metode ini menggunakan data time series sehingga lebih menggambarkan kualitas air dan metodenya mudah dipahami oleh masyarakat awam (Romdania et al., 2018).

Pada artikel ini penulis akan menyampaikan hasil kegiatan pemantauan kualitas air Sungai Cisadane secara online. Paparan ini diharapkan menjadi bahan komparasi dengan kegiatan pemantauan yang telah dilakukan sebelumnya dan menjadi rujukan untuk kegiatan pemantaun di perairan lainnya.

\section{METODE PENELITIAN}

\subsection{Lokasi Penelitian}

Pengambilan data penelitian ini dilakukan di tiga stasiun monitoring Sungai Cisadane (Gambar 1) milik Kementerian Lingkungan Hidup dan Kehutanan (KLHK) yang dibangun bekerjasama dengan Badan Pengkajian dan Penerapan Teknologi (BPPT). Stasiun 1 (STO 5) terletak di Bendungan Empang Bogor yang merupakan bagian hulu sungai dengan topografi yang lebih tinggi dan tata guna lahan di sekitranya sungai berupa bendung, pemukiman warga, industri, sedikit area lahan pertanian basah. Stasiun 2 (STO 6) terletak di Bendungan Pasar Baru yang merupakan bagian hilir sungai dan berada di kawasan pusat Kota Tangerang dengan tata guna lahan disekitranya berupa Bendung Pintu Air Sepuluh untuk irigasi, permukiman warga, dan industri. Stasiun 3 yang terletak di pos pemantauan sungai Cisadane Kota Tangerang yang merupakan bagian hilir sungai dan berada di dekat area permukiman warga dan industri. Peta lokasi pengambilan dan pengamatan data sampel dapat dilihat pada Gambar 2.

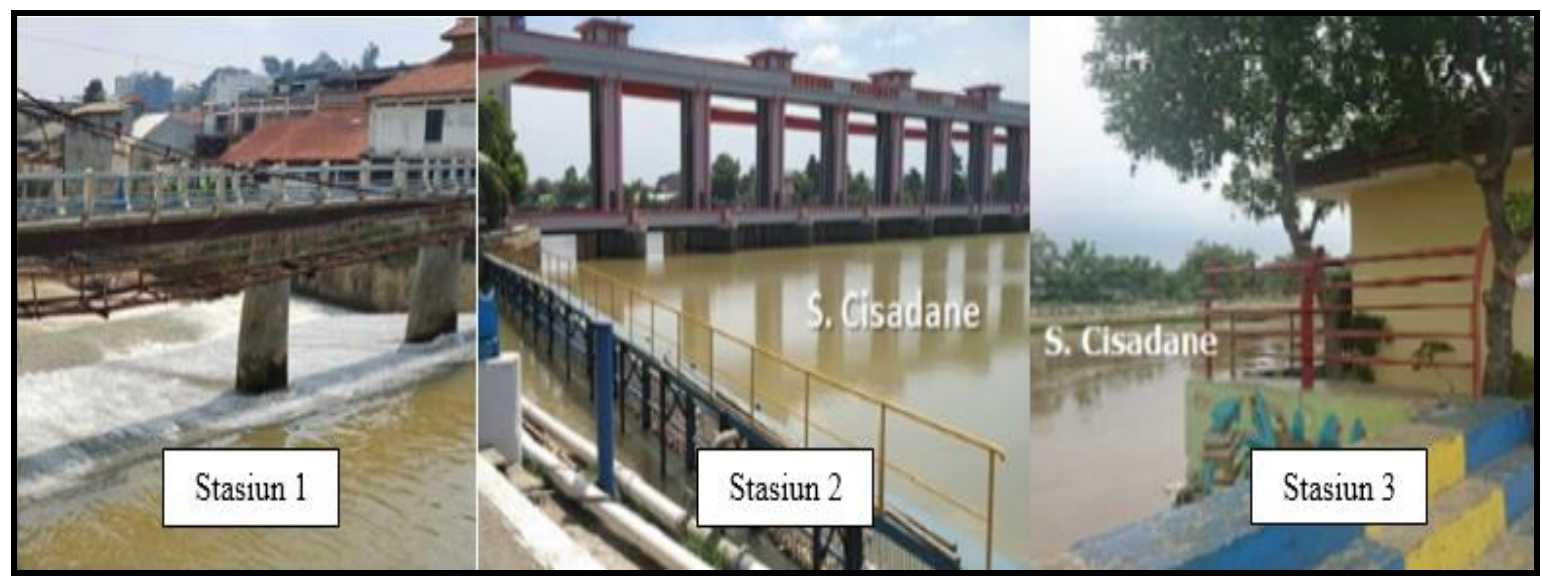

Gambar 1. Stasiun pengamatan 


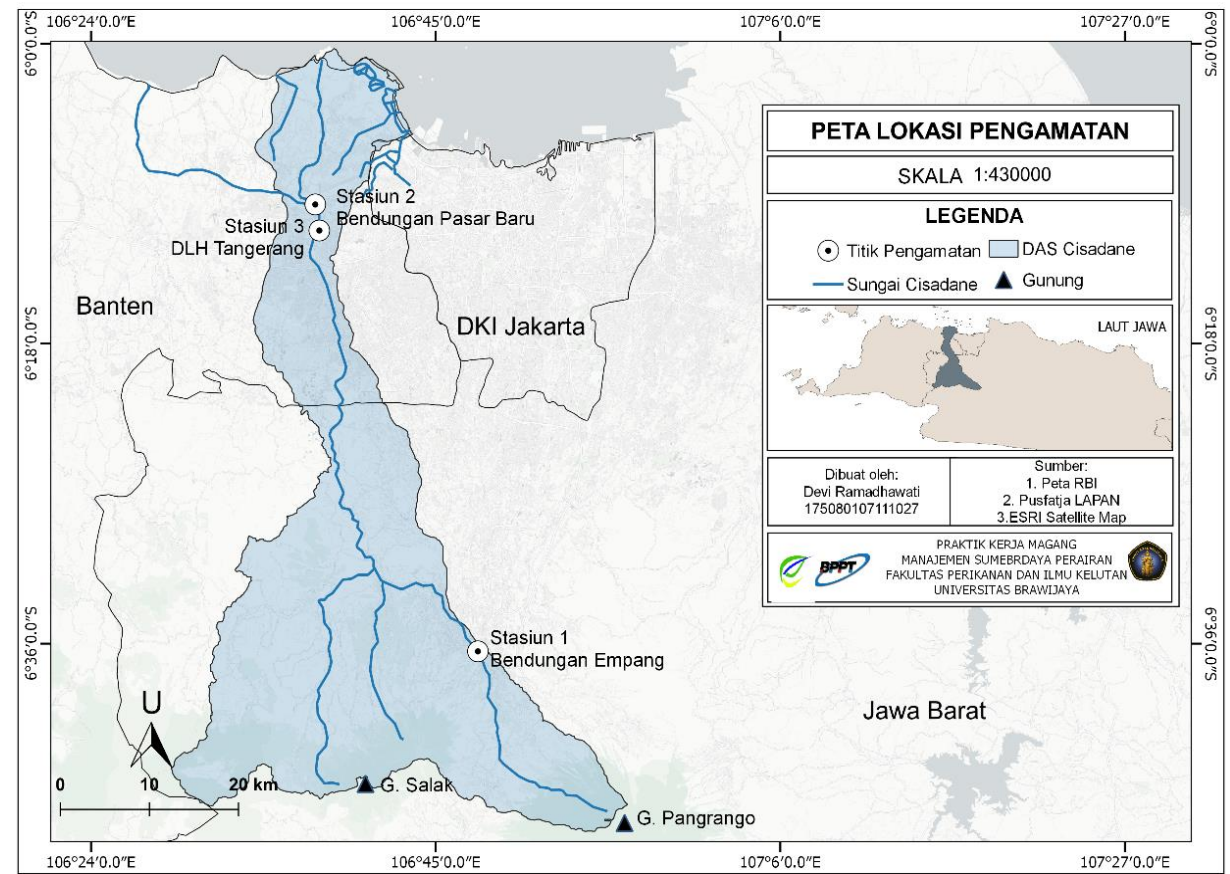

Gambar 2. Lokasi pengamatan

\subsection{Teknologi Telemetri Onlimo}

Pengambilan sampel pada ketiga stasiun pengamatan dilakukan dengan menggunakan teknologi telemetri Onlimo. Onlimo merupakan teknologi pemantauan kualitas air jarak jauh, secara online dan realtime yang telah dikembangkan oleh BPPT. Sensor Onlimo yang digunakan merupakan multiprobe sensor yang terdiri dari sensor parameter suhu, daya hantar listrik, TDS, kekeruhan, DO, pH, dan nitrat. Probe pada sensor yang digunakan telah dikalibarsi secara rutin dan berkala sebelumnya. Data hasil pengukuran kualitas air dari sensor tersebut akan disimpan sementara oleh data logger. Data logger yang digunakan memiliki dua jenis interval pemantauan yaitu secara periodik dan EWS/ early warning system, delay waktu pengukuran kualitas air untuk EWS adalah 60 detik. Interval pemantauan, penyimpanan dan pengiriman data dapat dimonitoring dari pusat data, serta memiliki onsite display untuk menampilkan hasil pengukuran setiap saat di lapangan. Spesfikasi dari sensor dan data logger dapat dilihat pada Tabel 1. Data kualitas air selanjutnya akan dikirim ke pusat data sesuai interval waktu yang telah diset, menggunakan media SMS (Short Message Service) dari provider GSM yang tersedia. Data yang telah diterima oleh pusat data akan dikelola oleh aplikasi software dan database Onlimo, sehingga dihasilkan data pengukuran realtime yang selanjutnya akan dianalisis. 
Tabel 1. Spesifikasi Sensor dan Data Logger

\begin{tabular}{ll}
\hline \multicolumn{1}{c}{ Sensor } & \multicolumn{1}{c}{ Data Logger } \\
\hline Multiprobe sensor & Serial RS-232 port : 1 main, 3 slave \\
\hline Output data analog atau digital (4-20mA) & 8 channel analog port \\
\hline Koneksi PC RS232C atau RS485C & $\begin{array}{l}8 \text { bit optocoupler TTL input, extendable to } 40 \\
\text { bit }\end{array}$ \\
\hline Data speed 1.200 11.520 bps & 4 bit Transistor output, extendable to 20 bit \\
\hline Data logging : cyclic atau noncyclic & 56 kByte flash memori \\
\hline Logging interval: $1 \sim 86.400$ detik & Real Time Clock \\
\hline Dilengakpi GPS & Dilengkapi PLC untuk EWS \\
\hline
\end{tabular}

\subsection{Analisis Data}

Data yang telah diperoleh dari sistem Onlimo kemudian dianalisis dengan menggunakan metode STORET. Metode STORET digunakan untuk menentukan tingkat pencemaran Sungai Cisadane dengan menggunakan parameter parameter suhu, DHL, TDS, kekeruhan, $\mathrm{DO}, \mathrm{pH}$, dan nitrat. Metode deskriptif digunakan untuk menggambarkan tingkat pencemaran kualitas air Cisadane.

Pedoman perhitungan metode STORET didasarkan pada Keputusan Menteri Negara Lingkungan Hidup No. 115 tahun 2003 tentang Pedoman Penentuan Status Mutu Air dan baku mutu air yang digunakan didasarkan pada Peraturan Pemerintah (PP) Nomor 82 Tahun 2001 tentang Pengelolaan Kualitas Air dan Pengendalian Pencemaran, peruntukan Kelas II yaitu untuk prasarana/sarana rekreasi air, pembudidayaan ikan air tawar, peternakan, air untuk mengairi pertanaman, dan atau peruntukan lain yang mempersyaratkan mutu air yang sama dengan kegunaan tersebut. Penentuan kelas II ini didasarkan pada pemanfaatan sungai Cisadane yang berfungsi sebagai sumber bahan baku air minum, rekreasi dan irigasi oleh masyarakat (Simanjuntak et al., 2016).

\section{HASIL DAN PEMBAHASAN}

\subsection{Suhu dan DO (Dissolved Oygen)}

Hasil pengukuran suhu dan DO periode Bulan Desember 2016 dapat dilihat pada Gambar 3 dan Gambar 4. Stasiun 1 memiliki memiliki nilai suhu $24,60-26,20^{\circ} \mathrm{C}$ dan DO $0-4,86$ $\mathrm{mg} / \mathrm{l}$; untuk Stasiun 2 memiliki suhu 26,78-29,43 ${ }^{\circ} \mathrm{C}$ dan DO 0-1,36 mg/l . Selanjutnya, hasil pengukuran pada Bulan Februari-Maret 2020 Stasiun 3 memiliki nilai suhu 26,40-29,34 ${ }^{\circ} \mathrm{C}$ dan DO 0,41-4,46 mg/l. 


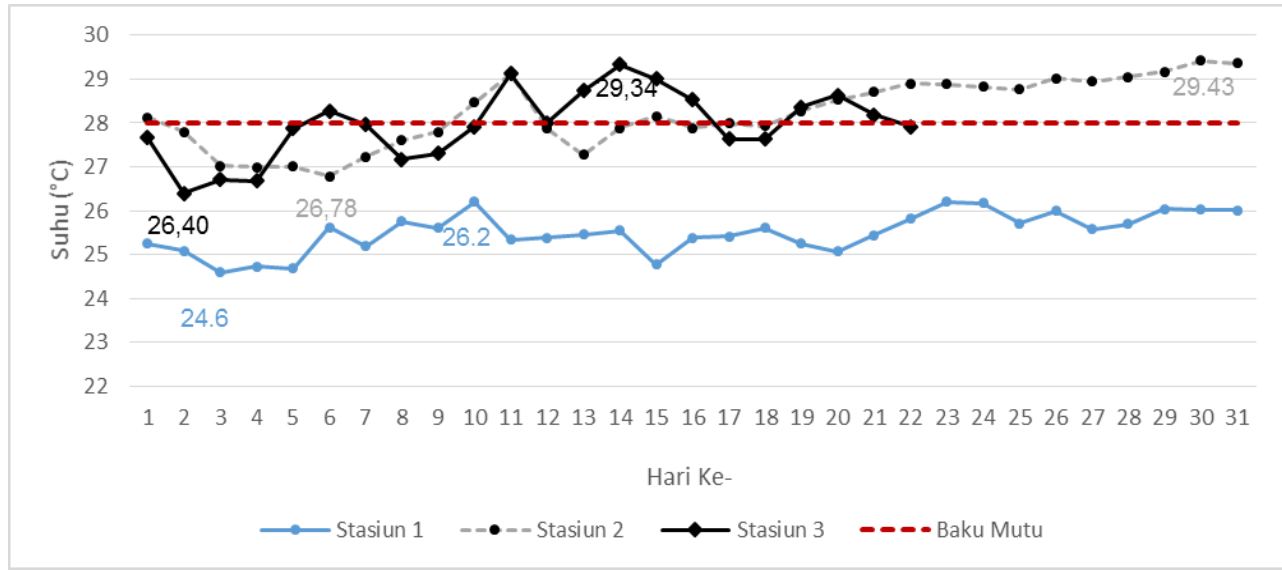

Gambar 3.Grafik pengukuran suhu

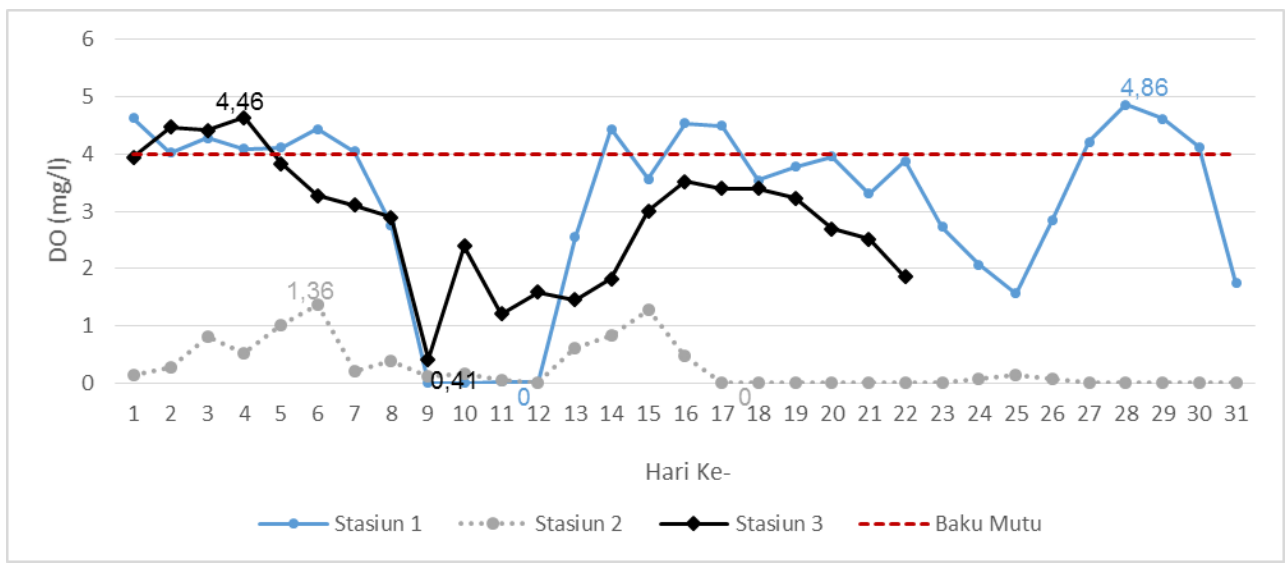

Gambar 4. Grafik pengukuran DO

Menurut Siahaan et al. (2011), suhu air Sungai Cisadane berkisar antara $23-30^{\circ} \mathrm{C}$ dan masih dalam kisaran suhu perairan tawar di Indonesia yaitu $21,3-31,4^{\circ} \mathrm{C}$. Secara umum suhu air sungai Cisadane (Gambar 3) bagian hulu relatif lebih rendah dibandingkan dengan bagian hilir. Hal tersebut dapat terjadi karena variasi suhu perairan dipengaruhi oleh topografi tempat. Menurut Suhmana (2012), daerah hulu sungai merupakan daerah yang tinggi, sehingga memiliki tekanan udara yang rendah akibatnya suhu udara maupun suhu air cenderung lebih rendah dibandingkan dengan daerah hilir yang memiliki tekanan udara lebih tinggi.

Kondisi DO pada ketiga stasiun (Gambar 4) masih belum memenuhi baku mutu DO sesuai PP No.82 tahun 2001 peruntukan Kelas II yaitu minimal $4 \mathrm{mg} / \mathrm{l}$ dengan nilai rata-rata DO terendah pada Stasiun 2. Variasi hasil pengukuran DO tersebut dapat dipengaruhi oleh buangan limbah. Menurunnya rata-rata harian DO dari bagian dari hulu ke hilir Sungai Cisadane, menggambarkan adanya peningkatan jumlah limbah dari sekitar lokasi. Effendi 
(2003), semakin ke hilir maka konsentrasi DO akan semakin menurun yang disebabkan karena adanya peningkatan proses dekomposisi bahan organik dan oksidasi bahan anorganik yang berasal dari buangan limbah. Selain itu, rendahnya konsentrasi DO di Stasiun 1 dapat dipengaruhi oleh tingginya nilai kekeruhan yaitu sebesar 13,89- 105,50 NTU. Menurut Sugainti dan Astuti (2018), tingginya nilai kekeruhan dapat menghambat proses difusi, sehingga konsentrasi oksigen terlarut akan menurun. Rendahnya konsentrasi DO di stasiun 2 dan 3dapat disebabkan karena adanya peningkatan bahan pencemar yang berasal dari permukiman, kawasan pertokoan, industri, perkantoran, pusat perbelanjaan dan pusat kuliner yang berada di sekitar lokasi pengamatan. Adanya bahan pencemar yang masuk ke sungai akan terbawa oleh aliran arus dan terakumulasi serta terdekomposisi, sehingga menyebabkan kandungan DO di bagian hilir menurun.

Kenaikan suhu di Stasiun 1 dan Stasiun 3 diikuti dengan menurunya konsentrasi DO. Hal tersebut dapat disebabkan karena suhu dapat mempengaruhi kelarutan oksigen di air. Menurut Muarif (2015), kenaikan suhu dapat menyebabkan tingkat kelarutan oksigen menurun. Selain itu, pada saat suhu meningkat aktivitas metabolisme organisme akuatik juga akan meningkat dan menggunakan oksigen dua kali lipat lebih banyak. Hal tersebut menyebabkan konsentrasi oksigen terlarut di perairan menurun. Pada Stasiun 2 dimana konsentrasi DO berbanding lurus dengan kenaikan suhu, hal tersebut dikarenakan suhu mempengaruhi proses fotosintesis yang mengasilkan oksigen. Menurut Urbasa et al. (2015), pada siang hari ketika matahari bersinar pelepasan oksigen saat proses fotosintesis berlangsung insentif lebih besar dari pada oksigen yang dikonsumsi oleh proses respirasi.

\subsection{TDS (Total Dissolved Solid), DHL (Daya Hantar Listrik) dan Kekeruhan}

Hasil pengukuran TDS, DHL dan kekeruhan periode Bulan Desember 2016 dapat dilihat pada Gambar 5, Gambar 6 dan Gambar 7. Stasiun 1 memiliki nilai TDS 0-100 mg/l; DHL 11,04-14,11 $\mu \mathrm{S} / \mathrm{cm}$ dan kekeruhan 13,89-105,50 NTU, sedangkan stasiun 2 memiliki nilai TDS 0-100 mg/l; DHL 11,57-16,67 $\mu \mathrm{S} / \mathrm{cm}$ dan kekeruhan 4,63-34,125 NTU. Hasil pengukuran periode bulan Februari-Maret 2020, Stasiun 3 memiliki nilai TDS 0-100 mg/l; DHL 0,7-14,73 $\mu \mathrm{S} / \mathrm{cm}$ dan kekeruhan 6,63-269,69 NTU. Nilai rata-rata pengukuran TDS pada ketiga stasiun (Gambar 5) memenuhi baku mutu PP No.82 tahun 2001 peruntukan Kelas II yaitu kurang dari 1000 mg/l. Penelitian sebelumnya oleh Budi et al. (2013), menyebutkan bahwa nilai TDS Sungai Cisadane pada tahun 2008 berkisar antara 62-104 mg/l. Konsentrasi TDS perairan dapat dipengaruhi oleh limpasan dari tanah dan pelapukan batuan. 


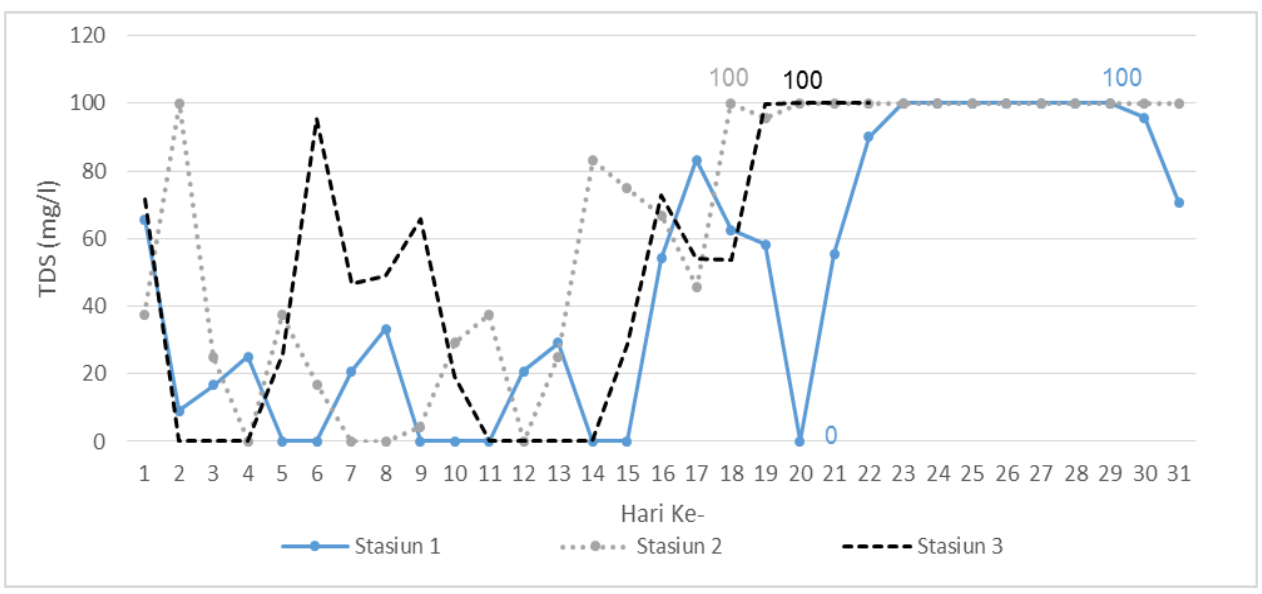

Gambar 5. Grafik pengukuran TDS

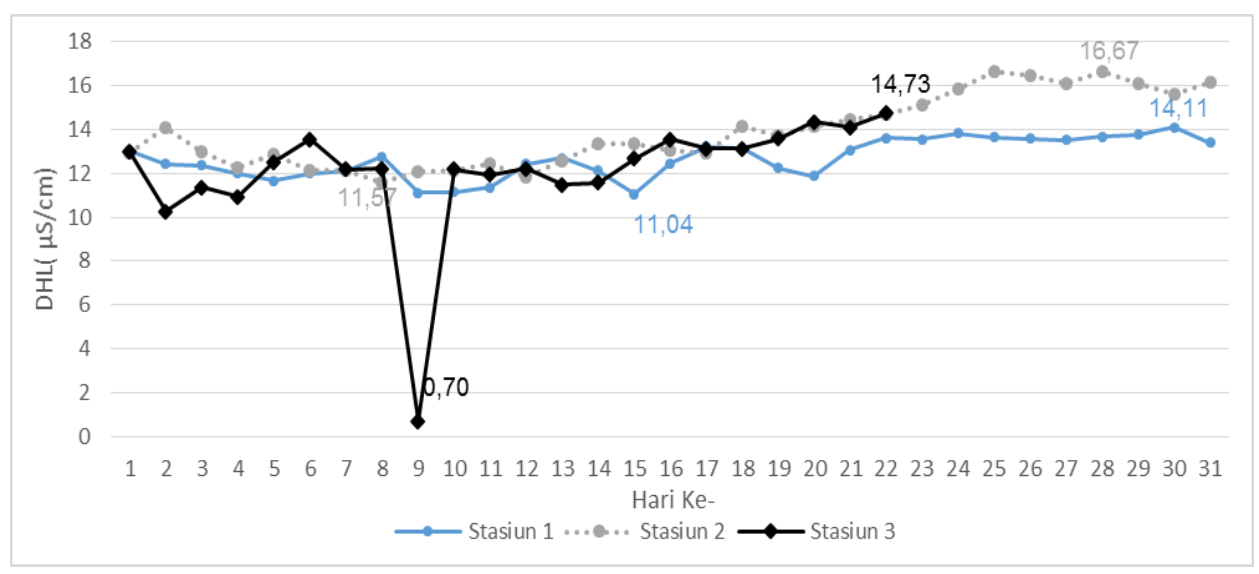

Gambar 6. Grafik pengukuran DHL

Menurut Ruseffandi dan Gusman (2020), daya hantar listrik pada air murni berkisar antara 0$200 \mu \mathrm{S} / \mathrm{cm}$ (low conductivity), pada sungai sungai berkisar antara 200-1000 $\mu \mathrm{S} / \mathrm{cm}$ (mid range conductivity), dan pada air saline adalah $1000-10000 \mu \mathrm{S} / \mathrm{cm}$ (high conductivity). Besarnya nilai TDS di perairan akan mempengaruhi nilai DHL. Menurut Astuti (2014), TDS dapat disebabkan oleh adanya bahan anorganik yang berupa ion-ion dan gas terlarut serta zat organik. Keberadaan ion-ion tersebut yang akan mempengaruhi nilai DHL (Gambar 6). Hasil pengamatan di atas, menunjukkan bahwa secara umum nilai TDS berfluktuasi dengan nilai DHL relatif rendah. Hal tersebut dapat dipengaruhi karena TDS di Sungai Cisadane diduga didominasi dari zat organik yang berasal dari limbah domestik, sehingga tingginya nilai TDS tidak diikuti dengan tingginya nilai DHL. Menurut Effendi (2003), kemampuan air dalam mengantarkan listrik bergantung pada tergantung keberadaan ion dan total konsentrasi ion. Semakin banyak garam garam terlarut yang dapat terionisasi, semakin tinggi pula nilai DHL, sebaliknya, semakin tinggi padatan terlarut yang berupa bahan organik (sukrosa dan benzene) 
yang tidak dapat mengalami disosiasi, maka semakin rendah nilai DHL.

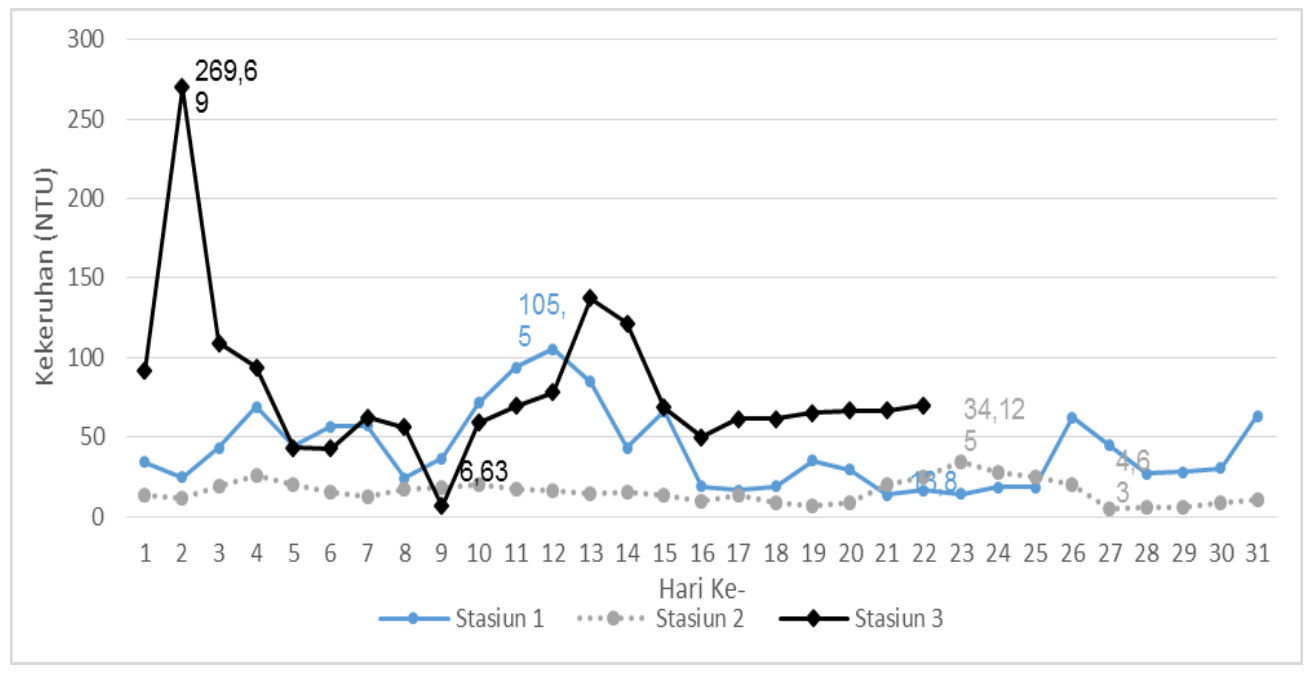

Gambar 7. Grafik pengukuran kekeruhan

Penelitian sebelumnya oleh Aisyah (2014), menyebutkan bahwa nilai kekeruhan Sungai Cisadane berkisar antara 18,8-192,7 NTU. Hasil pengamatan di atas (Gambar7), menunjukkan bahwa nilai rata-rata kekeruhan terendah pada stasiun 2. Nilai kekeruhan di perairan dapat dipengaruhi oleh limpasan sedimen dari daratan dan curah hujan. Tingginya kekeruhan di Stasiun 1 bagian hulu dapat disebabkan karena adanya erosi hulu sungai yang berada di daerah dataran tinggi. Aisyah (2014), memaparkan bahwa kekeruhan Sungai Cisadane yang relatif tinggi dapat disebabkan adanya peningkatan sedimentasi akibat erosi di bagian hulu. Selanjutnya, tingginya nilai kekeruhan di Stasiun 3, dapat disebabkan karena Stasiun 3 merupakan area hilir, sehingga terjadi akumulasi sedimen dan bahan lainnya yang terbawa oleh limpasan permukaan saat hujan. Sesuai pernyataan Siahaan et al. (2011), bahwa padatan tersuspensi dari hulu sungai akan terbawa ke hilir oleh aliran air. Hal tersebut menyebabkan adanya akumulasi, sehingga kekeruhan di bagian hilir juga semakin tinggi. Selain itu, berdasarkan data analisis iklim BMKG curah hujan tertinggi yaitu pada di Stasiun 3 sebesar 440,1 mm, diikuti Stasiun 1 sebesar 142,5 mm dan terendah Stasiun 2 yang hanya $120 \mathrm{~mm}$. Menurut Maturbongs (2015), curah hujan yang tinggi berkorelasi positif terhadap nilai kekeruhan perairan.

\section{3 pH dan DO (Dissolved Oxygen)}

Hasil pengukuran rata-rata harian $\mathrm{pH}$ periode Desember 2016 dapat dilihat pada Gambar 8. Pada Stasiun 1 berkisar antara 4,48-8,18 dan untuk Stasiun 2 berkisar antara 6,43- 6,80. Ratarata nilai pH pada Stasiun 3 periode Februari-Maret 2020 berkisar antara 4,48-6,98. 


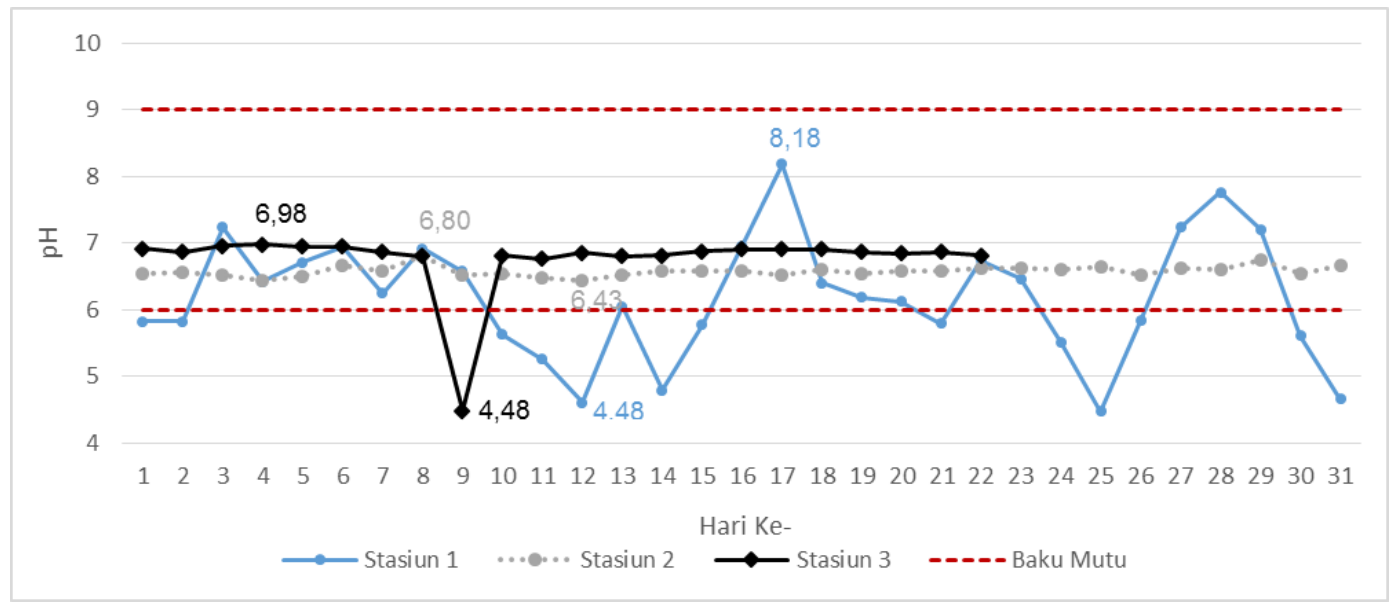

Gambar 8. Grafik pengukuran $\mathrm{pH}$

Hasil pengukuran rata-rata harian $\mathrm{pH}$ pada ketiga satsiun (Gambar 8), hanya Stasiun 2 yang secara keseluruhan memenuhi baku mutu PP No.82 tahun 2001 peruntukan Kelas II yaitu berkisar antara 6-9. Hasil pengamatan menunjukan bahwa nilai $\mathrm{pH}$ pada Stasiun 1 berfluktuasi, sedangkan pada stasiun 2 relatif sama serta pada Stasiun 3 hanya hari ke-9 yang mengalami penurunan. Menurut Siahaan, et al. (2011), pH Sungai Cisadane berfluktuasi antara 5-6,5 dan umumnya $\mathrm{pH}$ sungai berkisar antara 4-9.

Variasi nilai pH pada ketiga stasiun dapat dipengaruhi oleh curah hujan dan buangan limbah. Menurut Rizki et al. (2009), besarnya curah hujan akan mempengaruhi tingkat keasaman perairan yang ditunjukkan dengan rendahnya nilai $\mathrm{pH}$. Hal tersebut dikarenakan akan semakin banyak sulfat di atmosfer yang tercuci oleh air hujan sehingga nilai $\mathrm{pH}$ akan semakin menurun (Supriatin et al. 2017). Berdasarkan data iklim BMKG, curah hujan di bagian hulu relatif lebih rendah yaitu hanya sebesar $142,5 \mathrm{~mm}$, sehingga kisaran $\mathrm{pH}$ pada Stasiun 1 cenderung lebih besar. Selanjutnya, curah hujan tertinggi berada di Stasiun 3 yaitu sebesar 440,1 mm. Hal tersebut menyebabkan nilai rata-rata $\mathrm{pH}$ pada stasiun ini cenderung lebih rendah, terutama pada hari ke-9 dengan curah hujan sebesar $51.5 \mathrm{~mm}$ yang nilainya lebih tinggi dibandingkan dengan curah hujan harian dalam bulan Februari 2020. Selain itu, nilai rata-rata $\mathrm{pH}$ di bagian hilir (Stasiun 2 dan Stasiun 3) cenderung lebih asam dibandingkan dengan Stasiun 1 yang merupakan bagian hulu sungai. Suhmana (2012), menegaskan bahwa air dari dataran tinggi relatif mempunyai $\mathrm{pH}$ yang lebih tinggi, semakin ke hilir $\mathrm{pH}$ air akan menurun menuju suasana asam, hal ini disebabkan oleh adanya peningkatan bahan organik yang akan membebaskan $\mathrm{CO}_{2}$ jika terdekomposisi. Nilai $\mathrm{pH}$ di perairan juga berkaitan dengan konsentrasi DO dan karbon dioksida, dimana nilai $\mathrm{pH}$ akan menurun seriring menurunnya nilai DO. 
Menurut Kordi dan Tancung (2007), pada proses fotosintesis siang hari, fitoplankton atau tanaman air menyerap karbondioksida dan menghasilkan okesigen. Pada proses tersebut pH peraira akan meningkat. Sebaliknya, pada malam hari tanaman air dan fitoplankton mengonsumsi oksigen dan menghasilkan karbondioksida, sehingga kandungan pH perairan akan menurun.

\subsection{Nitrat}

Hasil pengukuran rata-rata harian nitrat pengukuran periode Desember 2016 dapat dilihat pada Gambar 9. Pada Stasiun 1 berkisar antara 0-17,93 mg/l dan dan untuk Stasiun 2 berkisar antara 0,07- 105,59 mg/l selanjutnya nilai periode februari Maret 2020 pada Stasiun 3 (DHL Tangerang) berkisar 1,23-2,43 mg/l.

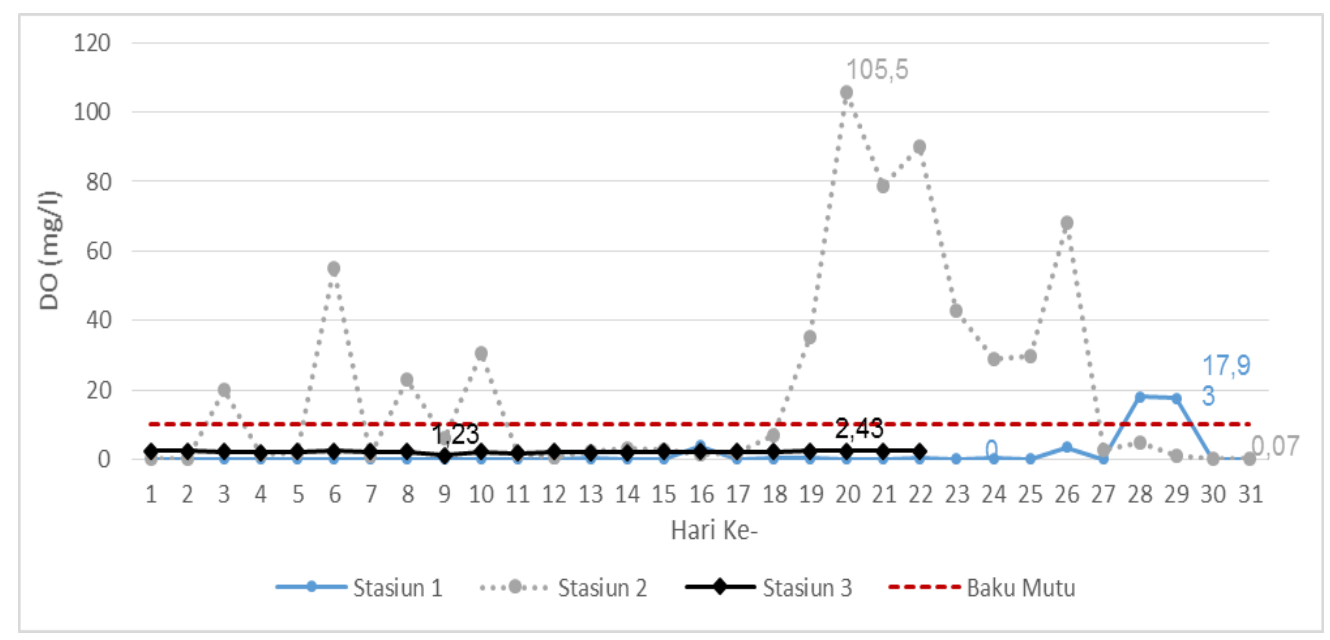

Gambar 9. Grafik pengukuran nitrat

Hasil pengamatan di atas (Gambar 9), menunjukkan bahwa secara umum nitrat bagian pada Stasiun 1 dan 2 lebih tinggi dibandingkan dengan Stasiun 3. Besarnya rata-rata kandungan nitrat dapat dipengaruhi oleh limbah yang berasal dari sekitar stasiun pengamatan. Adanya lahan pertanian basah di sekitar Stasiun 1 yang mengasilkan limbah pertanian dari pupuk, berpotensi meyebabkan kandungan nitrat meningkat. Menurut Suhmana, (2012), kegiatan pertanian tentunya akan menghasilkan limbah pertanian dari pupuk yang digunakan, yang melalui hujan akan tercuci, sehingga konsentrasi nitrat yang terlarut dan terbawa oleh run-off masuk ke badan sungai.

Tingginya nilai nitrat di Stasiun 2 dapat dipengaruhi oleh buangan limbah dari industri dan pemukiman padat di sekitar lokasi pengamatan. Semakin meningkatnya kepadatan penduduk di sekitar sungai dari hulu ke hilir menyebabkan pemanfaatan sungai sebagai sumberdaya air oleh masyarakat juga meningkat. Pemanfaatan sungai oleh masyarakat sekitar untuk kegiatan 
MCK dapat mempengaruhi konsentrasi nitrat di Sungai Cisadane. Menurut Hamuna et al. (2018), masuknya bahan pencemar dari aktivitas daratan yang dapat berupa erosi daratan, limbah rumah domestik, limbah pertanian yang terbawa run-off, dapat menyebabkan meningkatnya kandungan nitrat di perairan. Susana (2009), juga menyebutkan bahwa konsentrasi nitrat di Sungai Cisadane yang tinggi dapat disebabkan oleh kebiasaan masyarakat setempat yang melakukan kegiatan MCK di sepanjang aliran Sungai Cisadane banyak berdiri MCK yang berdampak pada meningkatnya pasokan nitrat ke dalam aliran sungai.

\subsection{Status Mutu Air Berdasarkan Metode STORET}

Penentuan status mutu dilakukan menggunakan metode STORET. Status mutu air pada stasiun 1, stasiun 2 dan stasiun 3 dapat dilihat pada Gambar 10, Gambar 11 dan Gambar 12.

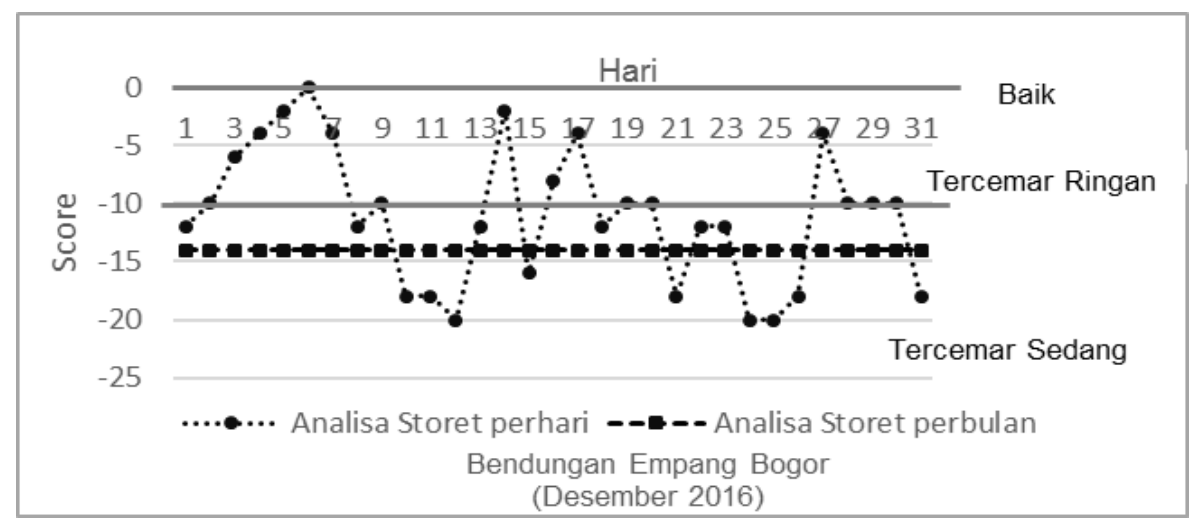

Gambar 10. Status mutu air di Stasiun 1 Bendung Empang

Tingkat pencemaran pada Stasiun 1 Bulan Desember 2016 (Gambar 10) berdasarkan metode STORET perhari, berada dalam kategori baik, tercemar ringan dan tercemar sedang dengan skor berkisar antara 0 sampai (-20), sedangkan berdasarkan analisa metode STORET perbulan berada dalam kategori tercemar sedang dengan skor (-14). Menurut Siahaan et al (2011), bagian hulu Sungai Ciadane telah tercemar, dimana semakin ke hilir kualitas airnya semakin menurun. Dari tujuh parameter yang digunakan, parameter yang tidak memenuhi baku mutu PP No.82 tahun 2001 Kelas II adalah parameter DO, pH dan nitrat. Adanya variasi nilai DO, pH dan nitrat dapat dipengaruhi oleh adanya bahan pencemar yang masuk ke badan sungai. Sesuai dengan tata lahan di sekitar Stasiun 1, bahan pencemar tersebut dapat berupa limbah domestik limbah industri, maupun limbah pertanian. Menurut Suhmana (2012), bahan organik yang terdapat pada limbah tersebut akan didekomposisi mengunakan oksigen yang berada di perairan dan akan membebaskan karbondioksida yang bersifat asam, sehingga $\mathrm{pH}$ 
di perairan juga menurun. Selain itu, limbah domsetik dan pertanian juga berpotensi meningkatkan konsentrasi nitrat di perairan.

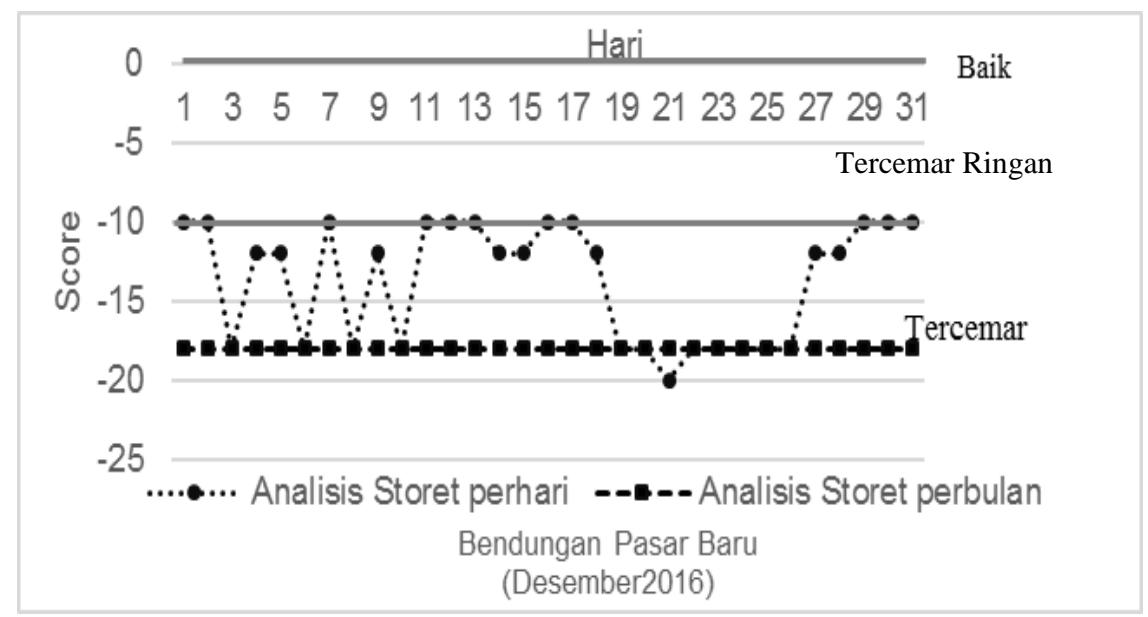

Gambar 11. Status mutu air di Stasiun 2 Bendung Pasar Baru

Tingkat pencemaran pada Stasiun 2 Bulan Desember 2016 berdasarkan metode STORET (Gambar 11), berada dalam kategori tercemar ringan dan tercemar sedang dengan skor berkisar antara (-10) sampai (-20), sedangkan berdasarkan analisa metode STORET perbulan berada adalam kategori tercemar sedang dengan skor (-18). Menurut Siahaan et al. (2011), sungai Cisadane bagian hilir telah tercemar parah sehingga tidak dapat digunakan untuk peruntukan Kelas 2, namun masih dapat digunakan untuk peruntukan kelas 3 dan 4. Dari tujuh parameter yang digunakan, parameter yang tidak memenuhi baku mutu PP No.82 tahun 2001 Kelas II adalah parameter DO dan nitrat. adanya variasi nilai DO dan nitrat dapat dipengaruhi oleh adanya bahan pencemar yang masuk ke perairan (effendi, 2003). Tata lahan di sekitar Stasiun 2, yang didominasi perumahan, industri dan perkantoran, limbah yang dihasilkan dapat berpotensi menurunkan nilai DO dan meningkatkan konsentrasi nitrat.

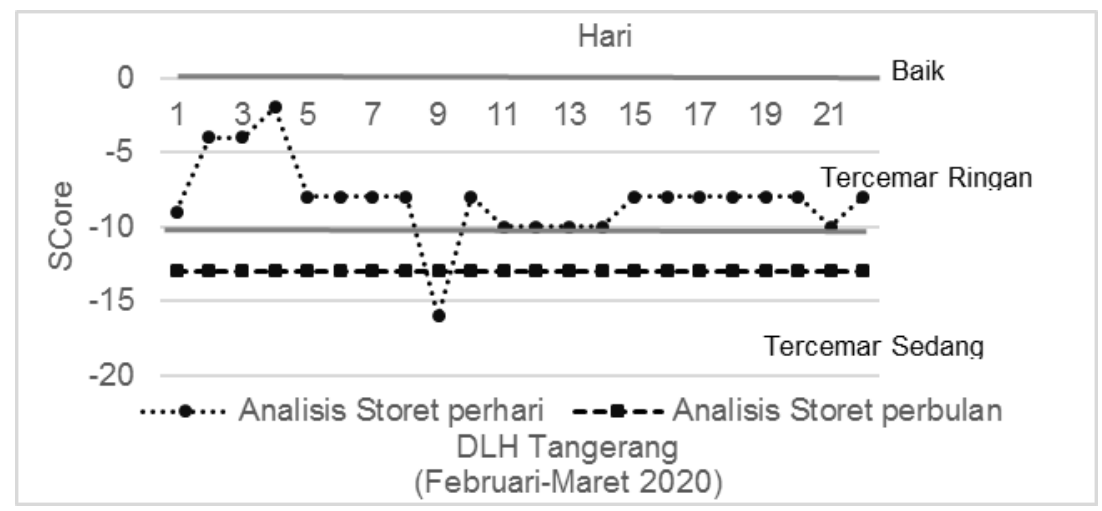

Gambar 10. Status mutu air di Stasiun 3 DLH Tangerang 
Tingkat pencemaran pada Stasiun 3 Bulan Februari-Maret 2020 (Gambar 12) berdasarkan metode STORET, berada dalam kategori tercemar ringan dan tercemar sedang dengan skor berkisar antara (-2) sampai (-16), sedangkan berdasarkan analisa metode STORET perbulan berada adalam kategori tercemar sedang dengan skor (-13). Menurut Siahaan et al. (2011), kualitas air sungai Cisadane pada bagian hilir telah tercemar parah (berat). Dari tujuh parameter yang digunakan, parameter yang tidak memenuhi baku mutu PP No.82 tahun 2001 Kelas II adalah parameter TDS, DO, pH dan nitrat. Adanya variasi nilai TDS, DO, pH dan nitrat dapat dipengaruhi oleh adanya bahan pencemar yang masuk ke badan sungai. Penggunaan lahan disekitar Stasiun 3 (DLH Tangerang) yang didominasi oleh pemukiman warga dan industri, berpontensi mengasilkan limbah domestik yang dapat menurunkan nilai DO dan pH serta meningkatan nilai TDS dan nitrat.

\section{KESIMPULAN}

Penerapan teknologi Onlimo di Sungai Cisadane dalam upaya pemantauan kualitas air dapat memberikan data kualitas air dan status mutu air secara kontinyu, online dan realtime. Dari data hasil pemantauan Onlimo yang telah dianalisis dengan metode STORET menunjukan status mutu air pada Bulan Desember 2016 termasuk dalam katergori tercemar sedang, dengan skor (-14) di Staisun 1 dan skor (-18) Stasiun 2. status mutu pada Bulan FebruariMaret 2020 di staisun 3 juga termasuk dalam katergori tercemar sedang, dengan skor yaitu (-13), sehingga secara keseluruhan Sungai Cisadane telah tercemar sedang. Dari ketiga stasiun, kualitas air Sungai Cisadane yang paling tercemar adalah Stasiun 2, yang ditandai dengan skor indeks Storet tertinggi.

\section{UCAPAN TERIMAKASIH}

Terimakasih kepada pembimbing lapang selama kegiatan PKM di Pusat Teknologi Lingkungan, Badan Penerapan dan Pengkajian Teknologi atas bimbingan, saran dan masukannya dalam penulisan artikel ilmiah ini.

\section{DAFTAR PUSTAKA}

Aisyah, S. (2014). Annual Water Quality Condition of Cisadane Downstream, West Java Banten. International Conference on Ecohydrology (ICE): Research Center For Limnology-Indonesian Institute Of Sciences, 405 - 413.

Astuti, A. D. (2014). Kualitas Air Irigasi Ditinjau dari Parameter DHL, TDS, pH pada Lahan Sawah Desa Bulumanis Kidul Kecamatan Margoyos. Jurnal Litbang: Media Informasi Penelitian, Pengembangan dan IPTEK, 10 (1): 35-42. 
Badan Meterologi, Klimatologi dan Geofisika. (2020). Curah Hujan di Indonesia. Diakses dari website : http://dataonline.bmkg.go.id.

Budi W, R. S., Rahayu, D dan Komariah, S. (2013). Efektifitas Riverbank Filtration Terhadap Parameter Fisik (TDS) di Sungai Cihideung. Jurnal Keteknikan Pertanian, 1 (1): 117-121.

Effendi, H. (2003). Telaah Kualitas Air Bagi Pengelolaan Sumber Daya dan Lingkungan Perairan. Yogyakarta: Kanisius.

Hamuna, B., Tanjung, R. H., Suwito, H. M. dan Alianto. (2018). Kajian Kualitas Air Laut dan Indeks Pencemaran Berdasarkan Parameter Fisika-Kimia di Perairan Distrik Depapre, Jayapura. Jurnal Imu Lingkungan, 16 (1): 35-43.

Hendrawan, D. 2005. Kualitas Air Sungai dan Situ di DKI Jakarta. Makara Journal of Technology. 9 (1): 13-19.

Keputusan Menteri Negara Lingkungan Hidup No.115 Tahun 2003 tentang Pedoman Penentuan Status Mutu Air. (2020). https://luk.staff.ugm.ac.id/atur/sda/KepmenLH115-2003StatusMutuAir.pdf.

Kordi, M. G. H dan Tancung, A. B. (2007). Pengelolaan Kualitas Air Dalam Budi Daya Perairan. Yogyakata: Rineka Cipta.

Maturbongs, M. R. (2015). Pengaruh Tingkat Kekeruhan Perairan Terhadap Komposisi Spesies Makro Algae Kaitannya dengan Proses Upwelling pada Perairan RutongLeahari. Agricola, 5 (1): 21-31.

Muarif, M. (2016). Karakteristik Suhu Perairan di Kolam Budidaya Perikanan. Jurnal Mina Sains, 2 (2): 96-101.

Namara, I., Kurniati, K dan Jaelani, R. (2016). Klasifikasi Kualitas Air Sungai Cisadane Kota Tangerang. Prosiding SENTRA (Seminar Teknologi dan Rekayasa), 48-56.

Pamungkas, R.S. (2017). Rancang Bangun Penerima Sinyal Berbasis Komunikasi Nirkabel Untuk Monitoring Kualitas Air. Universitas Pendidikan Indonesia.

Peraturan Pemerintah (PP) Nomor 82 Tahun 2001 tentang Pengelolaan Kualitas Air dan Pengendalian Pencemaran.

Rizki, T. Y., Tito C. K. dan Setiawan, A. (2015). Variasi pH di Perairan Indonesia. Balai Penelitian dan Observasi Laut.

Romdania, Y., Herison, A., Susilo, E. K dan Novilyansa, E. (2018) Kajian penggunaan metode IP, Storet, dan CCME WQI dalam menentukan status kualitas air. Jurnal Spatial, 18 (1): 1-13.

Rosarina, D dan Laksanawati, E. K. (2018). Studi Kualitas Air Sungai Cisadane Kota 
Tangerang Ditinjau dari Parameter Fisika. Jurnal Redoks, 3 (2): 38-43.

Ruseffandi, M. A dan Gusman, M. (2020). Pemetaan Kualitas Air Tanah Berdasarkan Parameter Total Dissolved Solid (TDS) dan Daya Hantar Listrik (DHL) dengan Metode Ordinary Kriging di Kecamatan Padang Barat, Kota Padang, Provinsi Sumatera Barat. Bina Tambang, 5 (1): 153-162.

Sari, S. G. (2007). Kualitas Air Sungai Maron dengan Perlakuan Keramba Ikan di Kecamatan Trawas Kabupaten Mojokerto Jawa Timur, Bioscientiae, 4 (1): 29-35.

Siahaan, R., A. Indrawan, D. Soedharma dan Lilik B. Prasetyo. (2011). Kualitas Air Sungai Cisadane, Jawa Barat-Banten, Jurnal Ilmiah Sains, 11 (2): 268-273.

Simanjuntak, W.S., Namara, I., Chayati, N dan Muhammad, F. (2016). Kajian Aspek Teknis Pada Peraturan Pengelolaan Kualitas Air. Prosiding Seminar Nasional Sains dan Teknologi 2016, Fakultas Teknik Universitas Muhammadiyah Jakarta, 1-5.

Sugianti, Y dan Astuti, L. P. (2018). Respon Oksigen Terlarut Terhadap Pencemaran dan Pengaruhnya Terhadap Keberadaan Sumber Daya Ikan di Sungai Citarum. Jurnal Teknologi Lingkungan, 19 (2): 203-212.

Suhmana, D. (2012). Dinamika Kualitas Air Sungai pada Berbagai Penggunaan Lahan di Sub DAS Cisadane. Departemen Ilmu Tanah dan Sumberdaya Lahan, Fakultas Pertanian, Institut Pertanian Bogor.

Supriatin, L. S., W. E. Cahyono dan Syafrizon. 2017. Pengaruh Kualitas Air Hujan Pada Konsentrasi Metana, Jurnal Kimia dan Pendidikan Kimia, 2 (2): 103-109.

Susana, T. (2009). Tingkat Keasaman (pH) dan Oksigen Terlarut Sebagai Indikator Kualitas Perairan Sekitar Muara Sungai Cisadane. Jurnal Teknologi Lingkungan Universitas Trisakt,5 (2): 33-39.

Urbasa, P.A., S. L. Undap, dan R. J. Rompas. (2015). Dampak Kualitas Air pada Budi Daya Ikan dengan Jaring Tancap di Desa Toulimembet Danau Tondano.e-Journal Budidaya Perairan, 3 (1):59-67.

Wahyono, H. D. (2018). Penerapan Teknologi Online Monitoring Kualitas Air di Indonesia. Prosiding Seminar Nasional dan Konsultasi Teknologi Lingkungan, 42-51. 